\title{
ANTIFUNGAL ACTIVITY OF SEAWEED ULVA LACTUCA L. EXTRACTED CRUDE PROTEIN AGAINST PATHOGENIC FUNGI
}

\author{
KRISHNAMOORTHI R ${ }^{1 *}$, SIVAKUMAR SR \\ Department of Botany, Bharathidasan University, Trichy, Tamil Nadu, India. Email: krishanmoorthi143@gmail.com
}

Received: 14 December 2018, Revised and Accepted: 19 January 2019

\begin{abstract}
Objective: The objective of this study was to evaluate the antifungal activity of seaweed extracted protein against the pathogenic fungi.

Methods: Antifungal activity of seaweed Ulva lactuca L. extracted protein was determined against pathogenic fungi such as Alternaria solani, Aspergillus clavatus, Aspergillus niger, Aspergillus flavus, and Fusarium oxysporum by disk diffusion Method. Then, the potentially active protein was determined using sodium dodecyl sulfate-polyacrylamide gel electrophoresis and circular dichroism (CD) spectroscopy.
\end{abstract}

Results: Seaweeds extracted protein checked for the antifungal activity against $A$. clavatus, $A$. solani, and $A$. flavus better activity compared to standard amphotericin-B and CD spectroscopy. Analysis of the extracts divulges the presence of entire protein compounds.

Conclusions: This study extracted seaweed protein sufficient of antifungal activity opposed to antifungal pathogens as compared with the standard. This is first report an activity of seaweed extracted protein against the plant and human pathogenic fungus bearing agricultural important.

Keywords: Bovine, Dichroism, Diffusion, Electrophoresis, Fungus, Protein.

(C) 2019 The Authors. Published by Innovare Academic Sciences Pvt Ltd. This is an open access article under the CC BY license (http://creativecommons. org/licenses/by/4. 0/) DOI: http://dx.doi.org/10.22159/ajpcr.2019.v12i3.30750

\section{INTRODUCTION}

Seaweeds are macroalgae which play an important role in ocean ecology and also being an important source of food, pharmaceutical as well as industrial products [1]. Bioactive compounds from seaweed are well known to have a great potential in pharmaceutical and biomedical applications. Several previously reported biomedical properties exhibited by seaweed include anti-inflammatory, antimicrobial, antioxidant, antihyperlipidemia, and anticoagulant [2-10]. Bioactivity of the compounds which has been isolated in recent years through the seaweed extract was used as novel drugs by the pharmaceuticals industries. Seaweeds are reported for their rich content of potential proteins The edible red seaweeds such as Palmaria palmata and Gracilaria cervicornis are having the highest protein content which possesses many potential biological activities [11,12] and seaweeds are good nutrition value such as carbohydrates, minerals, proteins, phenols, and good biofertilizer [13].

The ulvan species have been used as potential source for food preparation, bioenergy, feed and bioremediation etc. The nature content of proteins differs from one to another season and per species. The green seaweed $U$. lactuca L. possesses a protein level that reaches a maximum in August (32.7\% of dry weight) and minimum in April (8.7\% of dry weight) [14]. With this background of our knowledge and by using available reports the present studies was aimed to know the role of seaweed extracted protein against fungal pathogens.

\section{MATERIALS AND METHODS}

Materials

Ethanol, methanol, sulfuric acid, Whatman paper (No.1), ammonium hydroxide, diethyl ether, acetone, ammonium persulfate, acrylamide mix, tris, Coomassie Brilliant Blue (CBB)-R 250, acetic acid, sodium dodecyl sulfate (SDS), glycine, and amphotericin-B were used. All kinds of chemicals and kits were purchased from Sisco Research Laboratories Pvt., Ltd. (SRL), India.
Sample collection and preparation

The sample was collected from Ramanathapuram Mandapam region and authenticated Dr. M. Palanisamy, Scientist, Southern Regional Centre Botanical Survey of India, TNAU Campus, Lawley Road (PO), Coimbatore - 641 003, Tamil Nadu, India. The U. lactuca L. collected sample was washed with seawater for 5 times and further washed 2 times with distilled water to remove epiphytes, salts, sands, and contamination from other algae. The sample was air dried in shade condition at room temperature, and then, dried sample was homogenated and placed in plastic bags for further usage.

\section{Extraction of protein from seaweed}

The algal biomass ( $5 \mathrm{~g}$ ) was homogenized in a solution containing distilled water (DW, $2 \mathrm{~mL}$ ), 95\% ethanol (10 mL), and concentrated sulfuric acid ( $0.72 \mathrm{~mL}$ ) with uniform shaking for $20 \mathrm{~min}$. Again, $13 \mathrm{~mL}$ DW and $95 \%$ ethanol ( $40 \mathrm{~mL}$ ) were added, and the $\mathrm{pH}$ was adjusted to 1.7 using $\mathrm{HCl}$. The suspension was then filtered using Whatman paper (No. 1), and then again, the pH was adjusted to 3.0 using $\mathrm{NaOH}$. To this suspension, $140 \mathrm{~mL}$ of $95 \%$ ethanol and $190 \mathrm{~mL}$ diethyl ether were added and kept for $12 \mathrm{~h}$ at $4^{\circ} \mathrm{C}$. After centrifugation at $3000 \times \mathrm{g}$ for $10 \mathrm{~min}$, the sediment was washed with acetone and diethyl ether before dissolving in $25 \%$ ethanol and the $\mathrm{pH}$ was adjusted to 8.5 . The precipitate was collected by centrifugation after $18 \mathrm{~h}$ [15].

\section{Fungi}

Reference fungi name such as Aspergillus clavatus ATCC-9198, Fusarium oxysporum microbial type culture collection (MTCC)-1008, Alternaria solani ATCC-58177, Aspergillus niger MTCC-4285, and Aspergillus flavus MTCC 535 was obtained from MTCC, Chandigarh, India, and maintained in the laboratory. Other with ATCC was gifted by the Department of Microbiology, Bharathidasan University, Tiruchirappalli-24, Tamil Nadu, India.

\section{Protein Determination}

A modified Lowry et al. assay [16] described by Frolund et al. [17] was used to quantify the proteinaceous compounds in each seaweed 
extract. The principle of this modification is that the omission of copper sulfate from the reagent enables determination of the auto-absorbance from humic compounds and chromogenic amino acids. Concentrations and volumes of Lowry and Folin-Ciocalteu's phenol reagents (Sigma F9252) were optimized for speed and sensitivity. Ultimately, a more concentrated reagent compared to that of Lowry et al. (1951) was prepared to maximize assay sensitivity. A standard curve was made using bovine serum albumin (BSA; 0, 0.0625, 0.125, 0.25, 0.5, and $1 \mathrm{~g}$ $\mathrm{L}^{-1}$ ) and the absorbance was read at $650 \mathrm{~nm}$.

\section{SDS-polyacrylamide gel electrophoresis (PAGE)}

SDS-PAGE generally used to fractionate protein based on their molecular weight. The separation medium is a discontinuous gel on the basis of polyacrylamide and a voltaic field is negatively charged nucleic acid, or proteins of voltaic fields appeal over roam of the gel toward the anode. Molecular mosses of the protein were isolated by SDS. Non-cleavage and cleavage linked in a collection of monomers although covalent disulfide bonds persist intact. To view the protein it was stained with CBB. The evaluation can be done qualitatively with a plotted molecular weight size marker of known molecular weight [18].

SDS PAGE was executed by a mini-Protean III cell electrophoresis unit (Biorad, Hercules, CA, USA) with stacking gel of $5 \%$ and separating gel $10 \%$, acrylamide $30 \%$ in Tris- $\mathrm{HCl} 25 \mathrm{mM}$, pH 8.8, Glycine $0.18 \mathrm{M}$ and SDS $10 \%$. The separation was carried out at $100 \mathrm{~V}$ for $2 \mathrm{Hrs}$. The Bovine serum albumin $(67 \mathrm{kDa})$ polypeptides used as molecular mass marker. After migration, protein bands of algal protein extracts were detected by CBB staining. Protein bands were clearly viewed by CBB staining.

\section{Circular dichroism (CD)}

Far-UV CD scans were acquired using a Jasco J-815 spectrophotometer (Jasco, Inc., Easton, MD, USA) with a $10 \mu \mathrm{M}$ protein concentration in $20 \mathrm{mM} \mathrm{Na}_{2} \mathrm{HPO}_{4} / \mathrm{NaH}_{2} \mathrm{PO}, 100 \mathrm{mM} \mathrm{NaCl}$, pH 8 buffer. Spectrum in the range of 260-190 nm was recorded with a bandwidth of $1 \mathrm{~nm}$ and an integration time of $1 \mathrm{~s}$. Each spectrum was an average of 5 scans, with a scan rate of $50 \mathrm{~nm} / \mathrm{min}$. The mean residue ellipticity was calculated using the following formula (1):

$[\theta] \mathrm{MRE}=(\theta \mathrm{XMRW}) /(10 \mathrm{Xc} \mathrm{Xd})$

Where mean residue weight $=$ molecular weight $/(\mathrm{N}-1)$

"c" is a concentration of protein $(\mathrm{mg} / \mathrm{ml})$, "d" is the path length in $\mathrm{cm}$, and " $\mathrm{N}$ " is the number of amino acid.

\section{Antifungal assay}

Five fungal strains namely A. clavatus, F. oxysporum, A. solani, A. niger, A. flavus using for agar disc-diffusion method was followed to determine the antifungal activity. A suspension of inoculum was PDA medium (cooled to $40-45^{\circ} \mathrm{C}$ ) swirl gently to mix well. After solidification, sterilized filter paper discs $6 \mathrm{~mm}$ in diameter were impregnated with stock extracts and placed on the surface agar plate. Incubation period of $(08-12) \mathrm{Hrs}$ at $37^{\circ} \mathrm{C}$. The antifungal activity was evaluated by measuring zones of inhibition of fungal growth adjoining the seaweed protein extracts. For each test solution, two replicates were maintained (Sharma, 2011). The culture was incubated at $30^{\circ} \mathrm{C}$ for $1-5$ days and examined for all culture plates at 24 h onward $[19,20]$.

\section{RESULTS AND DISCUSSION}

The protein extraction and composition of different algal cell were studied (21) confirmation of the protein in seaweed were by first lane was obtained at 54-71 kDa, second lane at 33-43 kDa. The same band also confirmed at 2 and 3 rd lane sample. Sample (10, 15 and $20 \mu \mathrm{g}$ ) along with control were loaded and the targeted protein was identified. In comparison with control the thickness of the band was role in $20 \mu \mathrm{g}$ sample Fig 1.

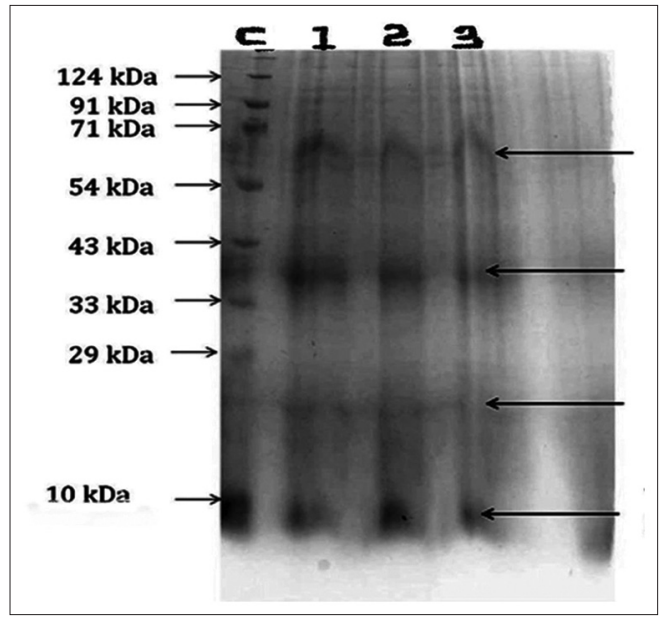

Fig. 1: Sodium dodecyl sulfate-polyacrylamide gel electrophoresis. C standard bovine serum albumin, 1-10 $\mu \mathrm{g}$ sample, 2-15 $\mu$ g sample, 3-20 $\mu$ g sample

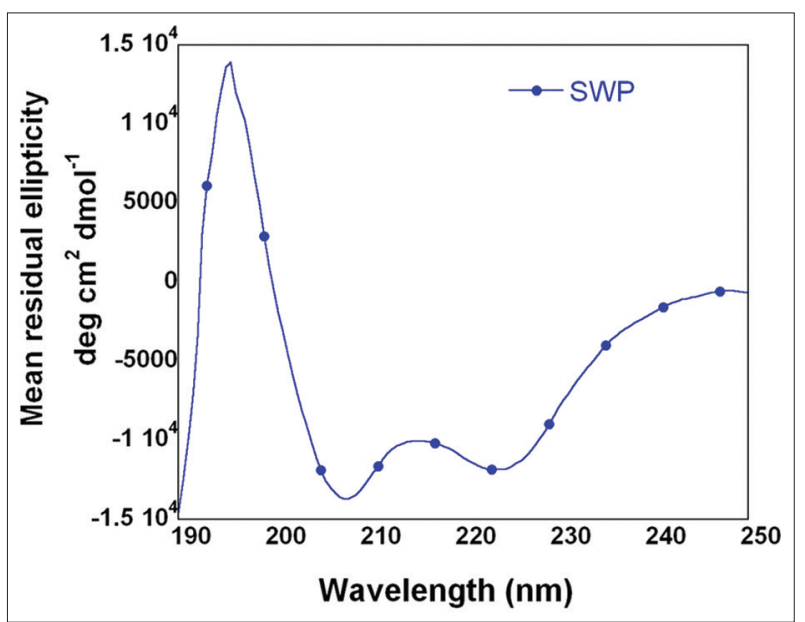

Fig. 2. Ulva lactuca L. crude protein secondary structure circular dichroism

A good resolution of proteins was observed for a gel with protein content starting with $15 \%$. For the experiments, $15 \%$ resolving gels were chosen, as the most convenient due to the shortest length. It contains several protein bands proving protein bands corresponding to molecular masses of 68, 41, 27, and $6 \mathrm{kDa}$. A gel electrophoresis (Fig. 1) indicates the presence of proteins in several spots.

CD

Far UV CD studies were performed to understand the secondary structural characteristic of SWP protein. Spectra showed the absorption minima at 208 and $222 \mathrm{~nm}$ suggesting the characteristic of $\alpha$-helical structure [22]. Further, the fractions of protein secondary structural elements were analyzed by K2D2, an online server for secondary structure estimation [23]. Secondary structure estimation showed $84.27 \%$ fraction of $\alpha$-helix and $1.24 \% \beta$ strand as shown in Fig. 2.

\section{Antifungal activity}

Water-soluble protein has consequence against pathogenic fungal organisms in this selection faintly active against $A$. solani, then good and more active founds in A. clavatus, A. niger, and A. flavus, finally less activity of the fungi $F$. oxysporum. In comparing with standard, seaweed extracted protein high efficacy against fungal pathogen Fig. 3, and Table 1. 


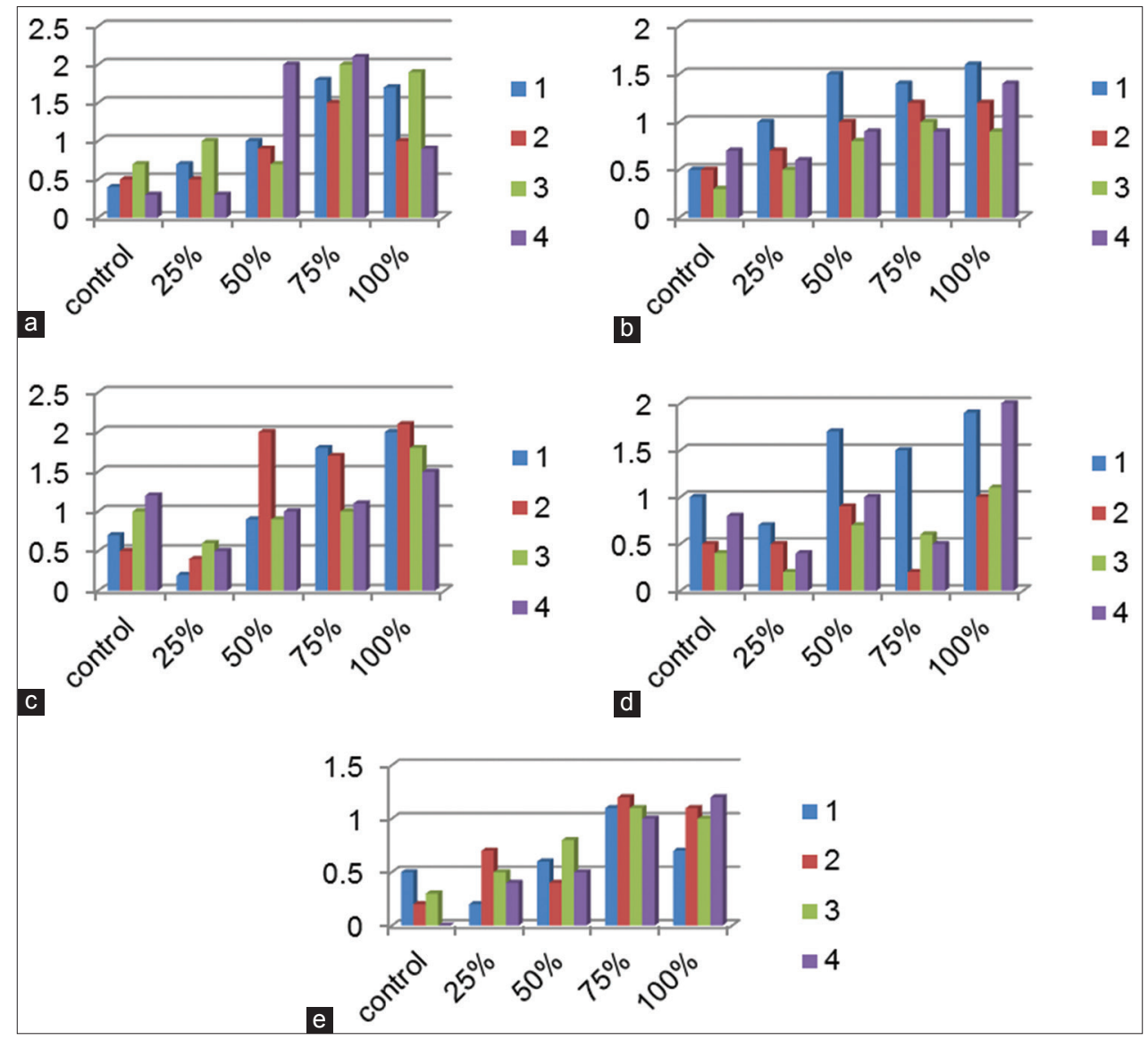

Fig. 3: Seaweed extracted protein in Ulva lactuca L. against fungus inhibition level. (a) Aspergillus clavatus, (b) Aspergillus niger, (c) Alternaria solani, (d) Aspergillus flavus, (e) Fusarium oxysporum

Table 1: Zone of inhibition extracted seaweed crude protein in Ulva lactuca L.

\begin{tabular}{|c|c|c|c|c|c|c|}
\hline \multirow[t]{2}{*}{ S. No. } & \multirow[t]{2}{*}{ Organism plant pathogens } & \multicolumn{5}{|c|}{ Diameter of the zone of inhibition extract concentration $(\mu \mathrm{g} / \mathrm{ml})(\mathrm{mm}$ value $)$} \\
\hline & & Control & $25 \%$ & $50 \%$ & $75 \%$ & $100 \%$ \\
\hline 1 & Aspergillus clavatus & $0.45 \pm 0.085$ & $0.25 \pm 0.14$ & $1.5 \pm 0.29$ & $0.22 \pm 0.13$ & $1.37 \pm 0.24+$ \\
\hline 2 & Fusarium oxysporum & $0.25 \pm 0.10$ & $0.18 \pm 0.10$ & $0.147 \pm 0.85$ & $0.14 \pm 0.85$ & $0.07 \pm 0.04$ \\
\hline 3 & Alternaria solani & $0.55 \pm 0.155$ & $0.14 \pm 0.08$ & $0.15 \pm 0.09$ & $0.15 \pm 0.09$ & $0.07 \pm 0.04 *$ \\
\hline 4 & Aspergillus niger & $0.5 \pm 0.81$ & $0.18 \pm 0.10$ & $1.5 \pm 0.155$ & $0.19 \pm 0.11$ & $1.27 \pm 0.14+$ \\
\hline 5 & Aspergillus flavus & $0.67 \pm 0.13$ & $0.18 \pm 0.10$ & $1.1 \pm 0.21$ & $0.39 \pm 0.22$ & $1.5 \pm 0.26+$ \\
\hline
\end{tabular}

C - Amphotericin+maximum inhibition *minimum inhibition - less inhibition

\section{CONCLUSIONS}

The finding of present study confirmed that, seaweed extract of $U$. Lactuca $L$. can be used/recommended as antifungal agent into preparing eco-friendly disinfectants. However further characterization showed be done. To the best of our knowledge this first report an U. Lactuca L. extract protein.

The water-soluble protein has consequence against pathogenic fungal organisms in this selection faintly active against $A$. solani, then good and more active found in A. clavatus, A. solani, and A. flavus, and finally, less activity of the fungi $F$ oxysporum. Moreover, antifungal activity effect expressed at this level. This statement provides strong conjectural evidence that antifungal potential plays a more important role in plants antifungal defense system. In study about anti-fungal activity further studies can be done by using other seaweed extract in to same pathogens to improve the metabolites quantities.

\section{AUTHORS' CONTRIBUTIONS}

R. Krishnamoorthi contributed in doing experiments and preparing the manuscript, and Dr. SR Sivakumar contributed in designing the experiment and put forwarded valuable suggestions.

\section{CONFLICTS OF INTEREST STATEMENT}

The author declared no conflicts of interest.

\section{ACKNOWLEDGMENT}

Author Krishnamoorthi R. thanking you to Bharathidasan University for Providing financial supports University Research Fellowship (URF - 10006/URF/K7/2017 Date: 31.03.2017).

\section{REFERENCES}

1. Waldvogel FA. Infectious diseases in the $21^{\text {st }}$ century: Old challenges and new opportunities. Int J Infect Dis 2004;8:5-12.

2. Cho SH, Kang SE, Cho JY, Kim AR, Park SM, Hong YK, et al. The antioxidant properties of brown seaweed (Sargassum siliquastrum) extracts. J Med Food 2007;10:479-85.

3. Kolsi RB, Frikha D, Jribi I, Hamza A, Feki L, Belghith K. Screening of antibacterial and anti fongical activity in marine macro algae and magnoliophytea from the coast of tunisha. Int J Pharm Pharm Sci 2015;7:47-51

4. Fitzgerald RJ, Harnedy PA. In vitro assessment of the cardioprotective, antidiabetic and antioxidant potential of Palmaria palmata protein 
hydrolysates. J Appl Phycol 2013;25:1793-803.

5. Heffernan N, Thomas S, Villa AS, Richard F, Nigel B. Phenolic content and antioxidant activity of fractions of obtained from selected Irish macroalgae species (Laminaria digitata, Fucus serratus, Gracilaria gracilis and Codium fragile). J Appl Phycol 2014;27:519-30.

6. Magalhaes KD, Costa LS, Fidelis GP, Oliveira RM, Nobre LT, DantasSantos N, et al. Anticoagulant, antioxidant and antitumor activities of heterofucans from the seaweed Dictyopteris delicatula. Int J Mol Sci 2011:12:3352-65.

7. Mancini-Filho J, Novoa AV, González AE, de Andrade-Wartha ER, de O e Silva AM, Pinto JR, et al. Free phenolic acids from the seaweed Halimeda monile with antioxidant effect protecting against liver injury. Z Naturforsch C 2009;64:657-63.

8. Higuera AR, Corona LQ, Castro NP, Ceballos GC, Garcia AM, Flores ME. Antioxidant enzyme gene expression and antihypertensive effect of seaweeds Ulva linza and Lessonia trabeculata in rats feed a high- fat and high- sucrose diet. J Appl Phycol 2013;26:597-605.

9. Sellimi S, Kadri N, Barragan-Montero V, Laouer H, Hajji M, Nasri M, et al. Fucans from a tunisian brown seaweed Cystoseira barbata: Structural characteristics and antioxidant activity. Int J Biol Macromol 2014;66:281-8.

10. Zhang $\mathrm{CY}$, Wu WH, Wang J, Lan MB. Antioxidant properties of polysaccharide from the brown seaweed Sargassum graminifolium (Turn.), and its effects on calcium oxalate crystallization. Mar Drugs 2012;10:119-30.

11. Arasaki TF, Mino N, Kuroda M. The protein value in human nutrition of edible marine algae in Japan. Hydrobilogia 1984;116:513-4.

12. Morgan KC, Wright JL, Simpson FJ. Review of chemical constituents of the red alga Palmaria palmate (dulse). Econ Bot 1980;34:27.
13. Rajasekar T, Shamya AM, Joseph J. Screening of phytochemical, antioxidant activity and anti-bacterial activity of marine seaweeds. Int J Pharm Pharm Sci 2019;11:61.

14. Abdel-Fattah AF, Sary HH. Selective isolation of glycoprotein materials from the green seaweed Ulva lactuca. Pak J Biochem 1987;20:61-5.

15. Khanna P, Nag TN, Chandrajaia S, Mohan S. Process for isolation of insulin from plant source. US Patent 1976;3:945-88.

16. Lowry OH, Rosebrough NJ, Farr AL, Randall RJ. Protein measurement with the folin phenol reagent. J Biol Chem 1951;193:265-75.

17. Frolund B, Griebe T, Nielsen PH. Enzymatic-activity in the activatedsludge floc matrix. Appl Microbiol Biotechnol 1995;43:755-61.

18. Whitford D. Proteins: Structure and Function. Hoboken, New Jersey, USA: Wiley; 2005

19. Krishnamoorthi R, Ayyadurai V, Marimuthu C. In-vitro antifungal activity of Naravelia zeylanica DC (Linn). J Nat Prod Plant Resour 2016;6:30-4

20. Barot M, Kumar JI, Kumar RN. Bioactive compound and antifungal activity of three different seaweed species Ulva lactuca, Sagassum renerrimum and Laurencia obtusa collected from OKha coast, Western India. J Coast Life Med 2016;4:284-9.

21. Wang SB, Hu Q, Sommerfeld M, Chen F. An optimized protocol for isolation of soluble proteins from microalgae for two-dimensional gel electrophoresis analysis. J Appl Phycol 2003;15:485-96.

22. Kelly SM, Jess TJ, Price NC. How to study proteins by circular dichroism. Biochim Biophys Acta 2005;1751:119-39.

23. Perez-Iratxeta C, Andrade-Navarro MA. K2D2: Estimation of protein secondary structure from circular dichroism spectra. BMC Struct Biol $2008 ; 8: 25$ 